\title{
UM ESTUDO SOBRE O ACENTO GRÁFICO NA AQUISIÇÃO DA ESCRITA: ORTOGRAFIA E FONOLOGIA
}

\author{
Luanda Alvariza Gomes Ney ${ }^{1 *}$ \\ ${ }^{1}$ Universidade Federal de Santa Catarina, Florianópolis, SC, Brasil \\ Ana Ruth Moresco Miranda $a^{2 * x}$ \\ ${ }^{2}$ Universidade Federal de Pelotas, Pelotas, RS, Brasil
}

\section{Resumo}

Neste texto discute-se os critérios utilizados pelas crianças dos anos iniciais referentes à função do acento gráfico no sistema de escrita. Considerando-se a estreita relação entre o acento prosódico e as regras de uso do acento gráfico pretendeu-se investigar as hipóteses das crianças em relação a este dispositivo ortográfico. Os dados analisados foram coletados a partir de um instrumento de escrita controlada criado especialmente para a pesquisa e de entrevistas orientadas pelo método clínico piagetiano (CARRAHER, 1989). Após a produção escrita as crianças foram provocadas, a fim de que explicitassem os motivos pelos quais utilizaram ou não o diacrítico em suas grafias. A análise dos dados de produção escrita mostra que as crianças acertam a grafia do acento preferencialmente nos contextos em que pode ocorrer a alternância de timbre da vogal tônica, ou seja, nas vogais médias e médias baixas. Os resultados das entrevistas apontam para a emergência de critérios baseados em correlatos acústicos e, também, em correlatos gráficos. Foi possível com a análise realizada definir uma hierarquia de critérios acústicos, a saber: timbre vocálico, duração e proeminência acentual.

Palavras-chave: Acento Gráfico; Acento Prosódico; Aquisição da Escrita; Ortografia-fonologia; Método Clínico

\section{A STUDY OF DIACRITICAL MARKS IN WRITING ACQUISITION: ORTHOGRAPHY AND PHONOLOGY}

\section{Abstract}

This paper discusses the criteria used by third and fifth graders who attend a public school, in Pelotas, RS, Brazil, regarding the function of diacritical marks in the writing system. Considering the close relationship between prosodic stress and the rules of use of diacritical marks, the study reported in this paper aimed at investigating children's hypotheses concerning these orthographic devices. Data were collected by a controlled writing

\footnotetext{
* Dra. em Educação(Universidade Federal de Pelotas). Coordenadora pedagógica do Núcleo de Desenvolvimento Infantil da Universidade Federal de Santa Catarina. Pesquisadora do Grupo de Estudos sobre a Aquisição da Linguagem Escrita (GEALE). Email: luandaalvariza@gmail.com ORCID https://orcid.org/0000-0002-29366378

${ }^{*}$ Dra. em Linguística (Pontifícia Universidade Católica do Rio Grande do Sul - PUCRS). Professora Associada da Universidade Federal de Pelotas. Bolsista de produtividade em pesquisa do CNPq. Email: anaruthmiranda@ hotmail.com. ORCID: https://orcid.org/0000-0002-1380-5751
} 
instrument, which was especially designed for this research, and by clinical interviews guided by the Piagetian method (CARRAHER, 1989). After completing a writing task, children were induced to explain the reasons that led them to use diacritics in their spelling. The analysis of data on their written production showed that children got the diacritical mark right, mainly in contexts in which alternation of vowel timbre could occur, that is, in medium and low medium vowels. Results of the interviews highlighted the emergence of criteria based on acoustic and graphic aspects. The analysis allowed us to define a hierarchy of acoustic criteria, i. e., vocalic timbre, vowel duration and prominence.

Keywords: Diacritical Mark; Prosodic Stress; Writing Acquisition; Orthography-phonology; Clinical Method 


\section{Introdução}

Neste artigo discute-se os critérios utilizados pelas crianças dos anos iniciais referentes à função do acento gráfico no sistema de escrita. O estudo originase de uma pesquisa que buscou investigar as respostas das crianças acerca da utilização do acento gráfico na ortografia do português, a fim de verificar como se estabelecem as relações entre o conhecimento linguístico, especificamente o fonológico, e a informação gráfica disponível.

O acento prosódico do português é um tema que concentra a atenção de estudiosos e pesquisadores dedicados aos estudos linguísticos há algumas décadas. Já o acento gráfico - um recurso da ortografia portuguesa utilizado para marcar a tonicidade das sílabas em palavras que extrapolam as tendências prosódicas da língua - é abordado, de modo geral, como algo arbitrário no sistema de escrita, cujas regras de utilização devem ser memorizadas, sem que haja reflexão sobre a motivação para a incidência do diacrítico nas palavras. Esta concepção equivocada sobre o acento gráfico pode acarretar problemas de aprendizagem relacionadas a este objeto de ensino durante o processo de aquisição da escrita, visto que, na maioria das vezes, os aprendizes não são levados a refletir sobre o porquê da necessidade ou não da acentuação gráfica, fato que pode ser atestado ao se observar as tradicionais gramáticas e os diversos materiais didáticos de língua portuguesa em circulação nas escolas, cujo foco sobre o acento recai predominantemente em torno da exposição de regras apresentadas como arbitrárias (NEY e MIRANDA, 2010).

Os dados analisados no estudo apontam para a emergência de critérios de utilização do acento gráfico baseados em correlatos acústicos e em correlatos gráficos. Entre os critérios vinculados a correlatos acústicos, identifica-se hipóteses sobre a função do acento relacionadas ao timbre vocálico, à duração e à proeminência acentual. Já para os correlatos de ordem gráfica, verifica-se a influência da memória visual como critério para justificar a grafia do acento. Neste texto serão descritos e analisados os critérios apresentados pelas crianças em que a função do acento gráfico é atribuída aos correlatos acústicos recém mencionados.

\section{Pressupostos para o estudo}

O ponto de partida para o desenvolvimento do estudo baseia-se em três premissas principais: i) a estreita relação entre o funcionamento do acento prosódico do português e as regras de utilização do acento gráfico previstos pela ortografia; (ii) a atualização do conhecimento fonológico da criança no processo de aquisição da escrita; e (iii) a aquisição da escrita como processo de formulação e reformulação de hipóteses as quais são como janelas para as formas de pensamento das crianças.

A primeira premissa é crucial para a concepção da pesquisa, visto que a ortografia do português brasileiro prevê o uso do acento gráfico apenas nos casos que extrapolam as tendências prosódicas da língua. De acordo com Bisol (1992, 1994) o acento do português é sensível ao peso silábico final e a língua constrói 
pés métricos binários com cabeça à esquerda, partindo da borda direita da palavra. Estas duas regras contemplam a maioria dos vocábulos do português e verifica-se, portanto, que os casos não marcados, isto é, as tendências prosódicas da língua, são as oxítonas terminadas em sílaba pesada e as paroxítonas terminadas em sílabas leves. A autora ainda prevê o recurso da extrametricidade e da cataláxis para explicar os casos considerados marcados. Nesse sentido, as três pautas acentuais podem ser explicadas por esta proposta:

oxítonas - casos não marcados: papai, amor, balão casos marcados: sofá, jacaré, robô

paroxítonas - casos não marcados: pipoca, tapete, livro casos marcados: açúcar, lápis, órfão

proparoxítonas - casos marcados: xícara, úmido, mágoa

Como se pode observar, os casos considerados prosodicamente marcados são aqueles querecebem, na escrita, a marcação gráfica por meio do uso de um diacrítico. A partir da relação entre o funcionamento prosódico da língua e a incidência do acento gráfico na escrita, pode-se considerar que o diacrítico funciona como um recurso visual capaz de indicar a marcação de tonicidade, informando ao leitor uma antitendência prosódica da língua.

A segunda premissa é referente ao papel do conhecimento fonológico no processo de aquisição da escrita. Os estudos desenvolvidos por Miranda (2009, 2012, 2014, 2018) mostram que a aquisição da escrita cria as condições necessárias à atualização do conhecimento fonológico já adquirido, o qual pode sofrer modificações a partir da compreensão dos princípios do sistema alfabético. Os estudos referentes às grafias das vogais átonas, das soantes palatais e das sílabas complexas, encontros consonantais e a grafia da nasalidade fonológica, oferecem sustentação à proposta de reestruturação das representações fonológicas construídas nos primeiros anos de vida pelas crianças.

A terceira premissa considera o fato de que a partir da perspectiva psicogenética de Ferreiro e Teberosky (1985), a competência linguística da criança e suas capacidades cognoscitivas passam a ser enfatizadas. Alicerçado nos pressupostos piagetianos, ${ }^{1}$ o programa de investigação desenvolvido pelas autoras revelou que ao longo do processo de aquisição da escrita as crianças constroem, refutam e reelaboram hipóteses, as quais apontam as diferentes estratégias de escrita e os respectivos percursos cognitivos percorridos na construção do conhecimento sobre a linguagem escrita. A partir da construção de situações experimentais e entrevistas clínicas (método da indagação) realizadas com crianças argentinas de quatro a seis anos, as autoras descreveram o processo de apropriação da escrita estabelecendo diferentes momentos de aquisição, os quais se articulam sistematicamente, constituindo, assim, um modelo de aprendizagem estruturado em níveis crescentes de complexidade e de aproximação da escrita convencional. ${ }^{2}$ 
Ney (2012), a partir de um corpus constituído de dados extraídos de aproximadamente 1000 textos produzidos por crianças dos anos iniciais, reveloutendências de utilização do acento gráfico pelas crianças. Foram analisados todos os contextos para a grafia do acento, bem como os usos não previstos pela ortografia, e os dados receberam tratamento estatístico. Os resultados mostraram erros em 53.6\% das palavras grafadas com preponderância da ausência do diacrítico em proparoxítonas, e, nos casos de uso indevido do acento, foi verificado o uso de diacrítico com a finalidade de marcar a abertura da vogal média. Entretanto, por se tratar somente de grafias observadas em documentos, sem a interação com aqueles que as produziram, não foi possível relacionar os índices encontrados com os critérios empregados pelas crianças na escolha por grafar ou não o acento, bem como a escolha pela sílaba a ser acentuada ou o tipo de acento grafado. Baseado da perspectiva de que os aprendizes da escrita elaboram e reelaboram hipóteses sobre os diversos aspectos da escrita, o presente estudo buscou identificar, descrever e analisar as hipóteses das crianças a respeito do acento gráfico, tendo como base os argumentos por elas utilizados para justificarem suas escritas.

\section{Procedimentos metodológicos}

Os dados analisados foram coletados a partir de um instrumento de escrita controlada criado especialmente para a pesquisa e de entrevistas orientadas pelo método clínico piagetiano (CARRAHER, 1989). O referido instrumento consiste em um ditado de imagens desenvolvido com o intuito de favorecer a produção da escrita de palavras-alvo acentuadas graficamente. $O$ ditado contempla palavras com estruturas proparoxítonas, paroxítonas e oxítonas, acentuadas graficamente, com as diferentes vogais distribuídas na posição tônica. ${ }^{3}$ No total, o instrumento é composto por 20 imagens, sendo que cinco representam palavras distratoras: macaco, computador, garfo, bicicleta e banana, e 15 representam palavras a serem analisadas no estudo. No quadro 01 estão expostas as palavras-alvo organizadas a partir das combinações entre qualidade da vogal, tipo de acento gráfico utilizado e pauta acentual:

Quadro 01 - Palavras-alvo do ditado de imagens, por qualidade da vogal, tipo de acento gráfico e pauta acentual

\begin{tabular}{|l|l|l|l|l|l|}
\hline \multirow{2}{*}{ grafema } & \multirow{2}{*}{ vogal } & \multirow{2}{*}{ tipo de acento } & \multicolumn{3}{|c|}{ pauta acentual } \\
\cline { 4 - 6 } & & & oxítona & paroxítona & proparoxítona \\
\hline \multirow{2}{*}{ 'a' } & $/ \mathrm{aN} /$ & circunflexo & -- & -- & lâmpada \\
\cline { 2 - 6 } & $/ \mathrm{a} /$ & agudo & sofá & lápis & -- \\
\hline \multirow{2}{*}{ 'e' } & $/ \mathrm{e} /$ & circunflexo & -- & tênis & -- \\
\cline { 2 - 6 } & $/ \varepsilon /$ & agudo & boné & -- & médico \\
\hline 'i’ & $/ \mathrm{i} /$ & agudo & abacaxi & vírus & príncipe \\
\hline \multirow{2}{*}{ 'o' } & $/ \mathrm{o} /$ & circunflexo & vovô & -- & -- \\
\cline { 2 - 6 } & $/ \mathrm{s} /$ & agudo & -- & automóvel & abóbora \\
\hline 'u' & $/ \mathrm{u} /$ & agudo & tatu & túnel & búfalo \\
\hline
\end{tabular}


As palavras produzidas servem como dados de análise do uso do acento em diferentes contextos ortográficos bem como funcionam como ponto de partida para reflexão e análise durante a entrevista clínica, realizada imediatamente depois da escrita do ditado.

A entrevista clínica caracteriza-se por ser uma estratégia metodológica na qual o pesquisador solicita ao sujeito que explique e justifique suas ações numa determinada atividade. Este método foi definido, portanto, com o intuito de extrair o máximo de informações possíveis de cada sujeito acerca do objeto pesquisado, de maneira que se pudesse confrontar suas justificativas com os dados por eles produzidos, problematizando-os e favorecendo as características do pensamento de cada sujeito, tal como caracterizou Carraher (1989, p.18): "a metodologia piagetiana procura voltar-se para a situação psicológica do sujeito, reconhecendo que a padronização de condições externas não pode satisfazer o requisito de colocar todos os sujeitos na mesma situação psicológica”.

Os dados apresentados neste texto foram produzidos por 14 crianças, 7 do terceiro ano e 7 do quinto ano do ensino fundamental de uma escola pública da rede municipal de Pelotas/RS. ${ }^{4}$ A coleta dos dados ocorreu ao longo do segundo semestre de 2018. A aplicação do instrumento ocorreu individualmente em espaço silencioso nas dependências da escola. A escrita das palavras-alvo foi precedida do reconhecimento prévio das imagens. Após a produção escrita as crianças foram provocadas a fim de que explicitassem os motivos pelos quais utilizaram ou não o diacrítico em suas grafias. Utilizou-se cartões-gabarito para cada palavra-alvo como recurso desencadeador das reflexões (cartões com a forma ortográfica devidamente acentuada). A condução da entrevista tinha como ponto de partida a leitura da palavra escrita pela criança e a comparação com o respectivo cartão-gabarito, cuja grafia havia supostamente sido escrita por outra(s) criança(s) de mesma faixa etária e etapa escolar que os participantes. Os ditados foram arquivados e as entrevistas foram gravadas para posterior transcrição e análise. Em seguida procedeu-se o levantamento de dados da tarefa de escrita e foi realizada a degravação das entrevistas.

\section{A grafia do acento nos dados de escrita}

Após a análise exploratória dos ditados, os dados de escrita produzidos foram classificados em cinco categorias definidas de acordo com os diferentes modos de utilização do acento gráfico nas palavras: acertos, omissões, grafia na sílaba inadequada, troca do tipo de acento e alterações de estrutura silábica. A fim de se descrever e analisar os critérios relacionados a correlatos acústicos sobre o acento gráfico, os dados de escrita coletados a partir do ditado de imagens serão brevemente descritos de acordo com a categorização proposta. Em seguida, as justificativas de grafias apresentadas pelas crianças serão tomadas como objeto de análise, de modo a possibilitar o exercício de reconstrução das hipóteses infantis sobre o acento a partir das respostas dadas nas entrevistas.

Na tabela 01, estão apresentados os índices correspondentes a cada item lexical: 
Tabela 01 - Panorama dos dados de escrita obtidos a partir do ditado de imagens

\begin{tabular}{|c|c|c|c|c|c|c|c|c|c|c|}
\hline \multirow[t]{2}{*}{ palavra-alvo } & \multicolumn{2}{|c|}{ acertos } & \multicolumn{2}{|c|}{ omissões } & \multicolumn{2}{|c|}{$\begin{array}{l}\text { grafia na } \\
\text { sílaba } \\
\text { inadequada }\end{array}$} & \multicolumn{2}{|c|}{$\begin{array}{l}\text { troca tipo de } \\
\text { acento }\end{array}$} & \multicolumn{2}{|c|}{$\begin{array}{l}\text { alterações } \\
\text { de estrutura } \\
\text { silábica }\end{array}$} \\
\hline & $3^{\circ}$ & $5^{\circ}$ & $3^{\circ}$ & $5^{\circ}$ & $3^{\circ}$ & $5^{\circ}$ & $3^{\circ}$ & $5^{\circ}$ & $3^{\circ}$ & $5^{\circ}$ \\
\hline sofá & 01 & 04 & 06 & 02 & -- & 01 & -- & -- & -- & -- \\
\hline lápis & -- & 06 & 06 & 01 & -- & -- & -- & -- & 01 & -- \\
\hline lâmpada & 01 & 02 & 06 & 04 & -- & -- & -- & -- & -- & 01 \\
\hline boné & 05 & 05 & 02 & 01 & -- & -- & -- & 01 & -- & -- \\
\hline tênis & 01 & 03 & 04 & 02 & 01 & -- & -- & 02 & 01 & -- \\
\hline médico & 03 & 04 & 03 & 03 & -- & -- & -- & -- & 01 & -- \\
\hline abacaxi & 07 & 07 & -- & -- & -- & -- & -- & -- & -- & -- \\
\hline vírus & 01 & 01 & 06 & 04 & -- & 02 & -- & -- & -- & -- \\
\hline príncipe & -- & 01 & 07 & 06 & -- & -- & -- & -- & -- & -- \\
\hline vovô & 05 & 07 & 01 & -- & -- & -- & 01 & -- & -- & -- \\
\hline automóvel & 01 & 02 & 06 & 04 & -- & 01 & -- & -- & -- & -- \\
\hline abóbora & 02 & 02 & 05 & 05 & -- & -- & -- & -- & -- & -- \\
\hline tatu & 07 & 07 & -- & -- & -- & -- & -- & -- & -- & -- \\
\hline túnel & -- & 04 & 06 & 03 & 01 & -- & -- & -- & -- & -- \\
\hline búfalo & -- & 01 & 07 & 06 & -- & -- & -- & -- & -- & -- \\
\hline subtotal & 34 & 56 & 65 & 41 & 02 & 04 & 01 & 03 & 03 & 01 \\
\hline total & \multicolumn{2}{|c|}{$90(43 \%)$} & \multicolumn{2}{|c|}{$106(50 \%)$} & \multicolumn{2}{|c|}{$06(3 \%)$} & \multicolumn{2}{|c|}{$04(2 \%)$} & \multicolumn{2}{|c|}{$04(2 \%)$} \\
\hline
\end{tabular}

Fonte: Ney (2018)

Como se pode observar na tabela 01 , as crianças acertaram 90 das 210 palavras-alvo, o que representa $43 \%$ do total. O percentual de omissão foi de $50 \%$ e os demais casos foram escassos e somam $7 \%$ das grafias. Somente duas palavras foram escritas de acordo com a norma ortográfica por todas as crianças: 'abacaxi' e 'tatu'. Como citado, ambas não recebem acento gráfico, visto que terminam, respectivamente, em /i/ e /u/. Estas palavras foram incluídas no ditado porque contemplam, dentre as combinações entre pautas acentuais e vogais, o acento oxítono com as vogais /i/ e /u/. Ainda que o objetivo do instrumento fosse estimular e coletar a escrita de palavras-alvo com acento gráfico, decidiu-se incluir as oxítonas terminadas em vogais altas para verificar se as crianças poderiam, ao identificar o pé troqueu mórico, grafar um acento indevido para indicar a tonicidade da última sílaba, o que não ocorreu.

Considerando o fato de que as oxítonas terminadas em vogais altas não recebem acento gráfico, torna-se importante observar os dados a partir da exclusão de 'abacaxi' e 'tatu' desta amostra. Desse modo, é possível analisar um grupo de 182 palavras-alvo, todas acentuadas graficamente. Neste universo, o número total de acertos cai para 62 (34\%), as omissões passam para 96 (58\%) e os demais casos somam 14 (8\%) ocorrências. A seguir, a figura 01 representa o percentual de distribuição dos dados produzidos no ditado de imagens em cada ano: 
Figura 01 - Percentual de distribuição de acertos, omissões e demais casos de grafia do acento produzidos no ditado de imagens no terceiro e no quinto ano

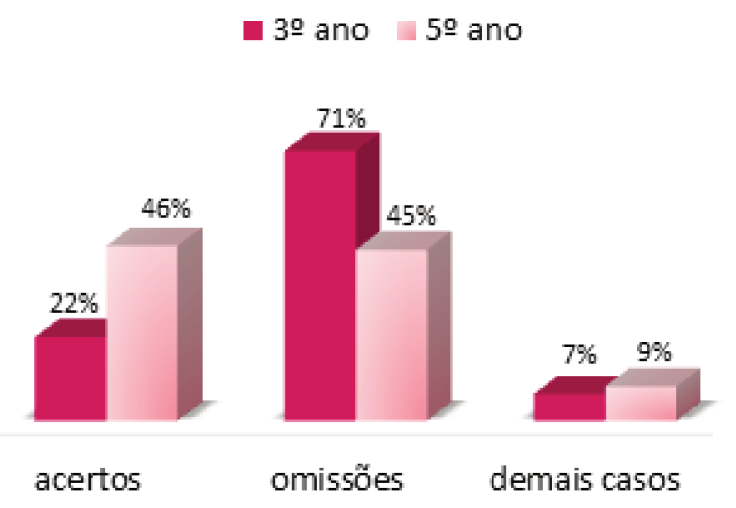

Fonte: Ney (2018)

Os índices mostram que as crianças do terceiro ano acertaram apenas $22 \%$ das palavras escritas no ditado, omitindo o diacrítico em $71 \%$ das grafias produzidas. O desempenho dos sujeitos do quinto ano em relação aos do terceiro revela efeitos do processo de escolarização, já que o percentual de acertos (46\%) representa mais que o dobro do terceiro (22\%). Ainda assim, o número de omissões no quinto ano é de $45 \%$, quase a mesma quantidade de acertos. Os demais casos encontrados nos dados somam, respectivamente, $7 \%$ e $9 \%$ para o terceiro e quinto ano.

\subsection{Acertos}

No grupo de dados considerados como acertos estão todas as palavras-alvo cujas grafias coincidem com o previsto pela norma ortográfica referente ao acento gráfico. ${ }^{5} \mathrm{~A}$ tabela 02 apresenta as palavras-alvo organizadas pelo número de acertos, considerando os dados do terceiro (20) e do quinto ano (42), os quais somam 62 ocorrências:

Tabela 02 - Ranking de acertos de grafia do acento produzidos no ditado de imagens, por item lexical

\begin{tabular}{l|l}
\hline palavra-alvo & acertos \\
\hline vovô & 12 \\
\hline boné & 10 \\
\hline médico & 07 \\
\hline lápis & 06 \\
\hline sofá & 05 \\
\hline tênis & 04 \\
\hline abóbora & 04 \\
\hline túnel & 04 \\
\hline lâmpada & 03 \\
\hline
\end{tabular}




\begin{tabular}{l|l}
\hline automóvel & 03 \\
\hline vírus & 02 \\
\hline príncipe & 01 \\
\hline búfalo & 01 \\
\hline total & 62 \\
\hline
\end{tabular}

Fonte: Ney (2018)

Nota-se que o maior número de acertos é referente a grafia da palavra 'vovô, ${ }^{6}$ seguida da palavra 'boné. Palavras bastante comuns ao léxico infantil, ambas oxítonas nas quais o acento gráfico agrega a informação de timbre à marcação da sílaba tônica. O elevado índice de acertos em 'vovồ e 'boné, em relação às demais palavras, pode ser interpretado, portanto, como efeito da alta frequência desses itens lexicais associada àinfluência do timbre vocálico. Em oposição, conforme se pode observar, as palavras-alvo com menor número de acertos no ranking são 'príncipe' e 'búfalo', as quais foram acentuadas por uma criança do quinto ano que gabaritou a escrita do ditado. Cabe observar que nestas palavras as vogais acentuadas não sofrem alternância de timbre.

\subsection{Omissões}

Os dados classificados como omissões são aqueles em que as crianças grafaram a palavra-alvo sem o seu respectivo acento gráfico. $\mathrm{O}$ ranking de palavras em que o acento foi suprimido pode ser visualizado na tabela 03 :

Tabela 03 - Ranking de omissões do acento gráfico produzidos no ditado de imagens, por item lexical

\begin{tabular}{l|l}
\hline palavra-alvo & omissões \\
\hline príncipe & 13 \\
\hline búfalo & 13 \\
\hline lâmpada & 10 \\
\hline abóbora & 10 \\
\hline automóvel & 10 \\
\hline vírus & 10 \\
\hline túnel & 09 \\
\hline sofá & 08 \\
\hline lápis & 07 \\
\hline tênis & 06 \\
\hline médico & 06 \\
\hline boné & 03 \\
\hline vovô & 01 \\
\hline total & 106 \\
\hline
\end{tabular}

Fonte: Ney (2018) 
Conforme os dados da tabela 03, o acento gráfico foi omitido por 13, das 14 crianças, ao escreverem as palavras 'príncipe' e 'búfalo'. Nota-se que se trata de palavras com formato prosódico proparoxítono, cujas sílabas tônicas têm na sua estrutura as vogais altas $/ \mathrm{i} / \mathrm{e} / \mathrm{u} /,^{7}$ as quais, como citado, não sofrem alteração de timbre; portanto, o acento gráfico atua nestas palavras exclusivamente como marcador de tonicidade. Na sequência, as palavras 'lâmpada', 'abóbora', 'automóvel' e 'vírus' foram grafadas sem o acento por dez crianças. Destas palavras, somente em 'vírus' o acento gráfico não acumula a função de indicação do timbre, assim como em 'túnel', a qual foi escrita sem o acento por nove crianças da amostra. Embora 'lâmpada,' 'abóbora' e 'automóvel' acumulem a informação sobre o timbre vocálico, fato que parece contribuir para a grafia adequada do acento, cabe considerar que tanto proparoxítonas quanto paroxítonas acentuadas graficamente tendem a favorecer o erro de escrita, tal como apontado por Ney (2012), cujos percentuais mostram que as pautas proparoxítonas e paroxítonas representam $51 \%$ dos dados de omissão do acento. Na mesma pesquisa, ao analisar o efeito da variável posição do acento na utilização do acento gráfico, a análise estatística apresentou pesos relativos. 30 para paroxítonas e .33 para proparoxítonas, em oposição ao peso de .63 atribuído aos monossílabos tônicos e oxítonas.

\subsection{Grafia na sílaba inadequada}

No grupo de dados classificados como grafia na sílaba inadequada foram incluídas as palavras em que o acento foi grafado, porém em sílaba diferente da tônica. Os dados em que o acento foi grafado dessa forma somam apenas seis ${ }^{8}$ ocorrências, sendo que em duas delas houve também a troca do tipo de acento. Na tabela 04 constam os exemplos das grafias produzidas desse modo pelas crianças:

Tabela 04 - Exemplos de ocorrências de grafia do acento na sílaba inadequada

\begin{tabular}{l|l}
\hline Exemplo & Ocorrências \\
\hline 'tenís' para 'tênis' & 01 \\
\hline 'sófa' para 'sofá' & 01 \\
\hline 'virús' para 'vírus' & 02 \\
\hline 'autômovel' para 'automóvel' & 01 \\
\hline 'tunéu' para 'túnel' & 01 \\
\hline total & $\mathbf{0 6}$ \\
\hline
\end{tabular}

Fonte: Ney (2018)

Esses dados, ainda que em pouca quantidade, remetem àqueles encontrados em Ney (2012) nos quais as crianças também grafaram o acento, porém em sílabas diferentes das tônicas. Assim como mencionado, a explicação mais plausível para esse tipo de grafia consiste na possibilidade de a criança estar acessando seu léxico ortográfico ao escrever; entretanto, sem apoio no seu conhecimento acerca do funcionamento do acento ortográfico, lança mão da memória visual ao grafar 
um diacrítico que ela sabe que tem, porém sem saber a exata posição, colocando -o em outra sílaba.

Em se comparando com os numerosos casos de omissão do acento, os casos de troca acima descritos, embora caracterizem erros ortográficos, atestam que ao menos o diacrítico foi grafado; ou seja, as crianças já atentaram à necessidade de grafia do acento, porém desconhecem o seu modo de funcionamento no sistema ortográfico e/ou têm dificuldades para identificar as sílabas tônicas das palavras.

\subsection{Troca do tipo de acento}

Nesta categoria foram incluídas as palavras em que as crianças trocaram o acento agudo pelo circunflexo ou vice-versa. O número de ocorrências também é baixo neste grupo, o qual contempla somente vogais médias e médias baixas, conforme exposto na tabela 05 :

Tabela 05 - Exemplos de ocorrências de troca do tipo de acento

\begin{tabular}{l|l}
\hline Exemplo & Ocorrências \\
\hline 'bonê' para 'boné' & 01 \\
\hline 'ténis' para 'tênis' & 02 \\
\hline 'vovó' para 'vovô' & 01 \\
\hline total & $\mathbf{0 4}$ \\
\hline
\end{tabular}

Fonte: Ney (2018)

Considerando-se a função do acento gráfico como indicador de tonicidade silábica, os casos exemplificados na tabela 05 poderiam ser considerados acertos, já que foram grafados na sílaba tônica da palavra. Entretanto, do ponto de vista da ortografia e da qualidade vocálica expressa pelo tipo de acento grafado, as quatro ocorrências representam erros, pois alteram a informação sobre o timbre das vogais acentuadas.

\subsection{Alterações de estrutura silábica}

As grafias em que houve alterações de estrutura silábica não foram consideradas dados de omissão, pois, ainda que o acento tenha sido suprimido, observa-se a ocorrência de outros fenômenos, tal como apresentados na tabela 06:

Tabela 06 - Exemplos de ocorrências de alterações de estrutura silábica

\begin{tabular}{l|l}
\hline Exemplo & Ocorrências \\
\hline 'laste' para 'lápis' & 01 \\
\hline 'endico' para 'médico' & 01 \\
\hline 'tesne' para 'tênis' & 01 \\
\hline 'lampda' para 'lâmpada' & 01 \\
\hline total & $\mathbf{0 4}$ \\
\hline
\end{tabular}

Fonte: Ney (2018) 
Dos quatro dados apresentados na tabela 06, três foram produzidos pela mesma criança, uma menina do terceiro ano. Verifica-se que ela produz metáteses ${ }^{9}$ intersilábicas em 'laste' e 'tesne', e intrassilábica em 'endico'. Nos primeiros casos, ao alterar a coda final para medial, elimina-se o peso silábico que justifica a grafia do acento para a manutenção do formato paroxítono das palavras 'lápis' e 'tênis'. Já em 'endico', há uma reestruturação que forma uma paroxítona. Neste caso, a grafia do acento ainda seria necessária para manter a marcação do acento proparoxítono.

Em 'lampda', produzido por uma menina do quinto ano, a omissão da vogal 'a' originou uma estrutura paroxítona na qual o processo de ressilabificação alterou a posição de /p/, do onset para coda: lamp.da. Esse processo de síncope em proparoxítonas é comum entre os falantes do português brasileiro (AMARAL, 2000) e também presente em dados de escrita, conforme Ney (2012).

Os quatro casos de alterações de estrutura silábica encontrados configuramse como grafias muito particulares, produzidas em pouca quantidade, mas, assim como os demais dados analisados, podem ser indicativos de hipóteses infantis sobre os recursos gráficos disponíveis no sistema, em especial, sobre o acento gráfico. As justificativas de grafia para os dados apresentados na tabela 06 são imprecisas e, de modo geral, indicam que as crianças têm dificuldade para explicar os critérios empregados na escrita das referidas palavras.

\section{Entrevistas clínicas}

Nesta seção, estão apresentados os dados obtidos a partir das entrevistas clínicas realizadas com as crianças após a produção escrita no ditado de imagens. Como referido, este texto contempla a descrição e a análise dos critérios de utilização do acento gráfico baseados em correlatos acústicos apresentados pelas crianças. Tais critérios abrangem as justificativas das crianças que demonstram hipóteses para a função do acento relacionadas a aspectos como frequência dos formantes, ressonância, duração e intensidade. Serão apresentadas inicialmente as hipóteses relacionadas à frequência dos formantes e à ressonância, as quais podem ser observadas no grupo de respostas alusivas à variação do timbre das vogais acentuadas, orais e nasalizadas. Na sequência, pode-se observar as hipóteses referentes ao correlato de duração, através das justificativas de necessidade do acento baseadas no alongamento/duração da vogal acentuada e, por último, as justificativas baseadas na tonicidade/proeminência/volume, as quais correspondem ao correlato acústico de intensidade.

Considerando a natureza metodológica deste estudo, é importante salientar que as entrevistas clínicas não são lineares, uma vez que seu desenvolvimento ocorre de acordo com as peculiaridades de cada sujeito. Desse modo, os dados referentes às entrevistas clínicas não são quantificáveis e tampouco passíveis de uma única interpretação. Isso significa, por exemplo, que uma mesma criança pode ter apresentado diferentes justificativas para a mesma palavra, as quais podem estar assentadas em mais de uma hipótese. Na des- 
crição a seguir, devem ser consideradas, portanto, a ideia de concomitância e/ou sobreposição de hipóteses.

\subsection{Justificativas baseadas no timbre vocálico}

Foram classificadas nesta categoria todas as explicações apresentadas pelos sujeitos com menção ao timbre vocálico como critério para a necessidade de grafia do diacrítico. Esta hipótese sobre a função do acento gráfico é a mais frequente entre as respostas das crianças, tanto do terceiro quanto do quinto ano. Além disso, é possível observar que as justificativas de grafia do acento para abertura do timbre são aquelas em que as crianças demonstram ter mais convicção acerca dos motivos por que utilizaram o diacrítico.

A constatação ora apresentada, sobre a hipótese de o acento gráfico funcionar como indicador de timbre vocálico, é predominante dentre as justificativas correspondentes aos itens cuja vogal tônica é média baixa: 'boné,' 'abóbora', 'médico' e 'automóvel', todas grafadas com acento agudo. Para estas palavras, a justificativa vinculada ao timbre é unânime entre os 14 sujeitos. Somente uma criança, do quinto ano, atribuiu a necessidade de grafia do acento à tonicidade nessas palavras, e ainda assim, mencionou a qualidade da vogal como um critério concomitante para a necessidade de utilização do acento. Quando convidadas a tentarem ler as palavras sem o acento, a maioria conserva seu desenho prosódico, alterando somente o timbre da vogal acentuada: [bo’ne]; ['medfiku], por exemplo.

Entre as explicações referentes ao acento gráfico em vogais médias altas, casos em que se usa o circunflexo, a hipótese a respeito do timbre é menos representativa: para 'tênis', esse critério é apontado somente duas vezes, e para 'vovô', quatro vezes.

Nos contextos que envolvem a tonicidade da vogal baixa, metade das crianças tende a justificar o acento de 'lâmpada' pelo timbre nasal. Para 'lápis', há apenas dois registros de hipóteses relativas ao timbre e para 'sofá, um registro. Quando questionadas sobre o modo como estas palavras ficariam sem o acento, as crianças que apresentaram esta hipótese nasalizaram a vogal baixa: [so'fã]; ['lãpis], mantendo seus formatos prosódicos e alterando somente o timbre. O mesmo ocorreu na leitura de 'lâmpada' sem o acento, casos em que se observou a dificuldade das crianças para desnasalizar a vogal tônica.

No quadro a seguir, estão apresentados alguns exemplos de justificativas de grafia que denotam as hipóteses das crianças sobre a função do acento gráfico atribuída à indicação de timbre ${ }^{10}$ : 
Quadro 02 - Exemplos de justificativas de necessidade de grafia do acento relacionadas ao timbre vocálico

\begin{tabular}{|c|c|c|}
\hline vogal & palavra & exemplos de justificativas \\
\hline [a] & lápis & $\begin{array}{l}\text { Porque também faz um som diferente, LÁPIS... faz um som mais fino } \\
\text { Que som mais fino é esse? } \\
\text { É que... tipo, fica 'LA', só que às vezes tem algumas palavras que têm 'LÃ' }\end{array}$ \\
\hline$[\tilde{\mathbf{a}}]$ & lâmpada & $\begin{array}{l}\text { LÂM-PADA, e aí, esse daqui ele fica mais pra baixo, e o outro fica mais pra } \\
\text { cima. E aí esse daqui ficou mais LÂMPADA, LÂM... } \\
\text { Ele deixa mais pra baixo (fez sinais com as mãos) }\end{array}$ \\
\hline \multirow{5}{*}[\varepsilon]{} & \multirow{2}{*}{ boné } & $\begin{array}{l}\text { Para ele fazer sentido...BO-NÉ (enfatiza o timbre aberto) } \\
\text { Hum...pra fazer o quê?? } \\
\text { Pra escrever BONÉ, porque senão fica BONÊ }\end{array}$ \\
\hline & & $\begin{array}{l}\text { É que nem no médico, diferencia aqui no -NÉ...essa aqui que é 'NÉ' } \\
\text { Ah, se tirar o acento do boné fica como a palavra? } \\
B O N E\end{array}$ \\
\hline & \multirow{3}{*}{ médico } & Pra formar 'MÉ'...pra dar um som no 'e' \\
\hline & & O MÉDICO, ele tem que ter acento senão ficaria MÊDICO, 'MÊ' \\
\hline & & Serve para deixar a palavra...a sílaba mais aguda[...]mais...mais fino \\
\hline \multirow{4}{*}{ [0] } & \multirow{2}{*}{ abóbora } & $\begin{array}{l}\text { Porque senão ia ficar [a'bobora][...] } \\
\text { É...com um som...ficaria um som mais grosso }\end{array}$ \\
\hline & & $\begin{array}{l}\text { pra formar...ABÓ....pra formar o 'BÓ' (...) } \\
\text { Aí, sem o acento fica bô...[a'bobora] }\end{array}$ \\
\hline & \multirow{2}{*}{ automóvel } & $\begin{array}{l}\text { É que se tirar o acento fica...AUTOMÔVEL } \\
\text { Ele tá deixando o som mais fino, que nem o médico, só é mais fino. }\end{array}$ \\
\hline & & $\begin{array}{l}\text { porque, como eu te disse também, pra deixar a palavra mais aguda, } A U \text { - } \\
\text { TOMÓVEL, senão ficaria AUTOMÔVEL }\end{array}$ \\
\hline
\end{tabular}

Fonte: Elaboração própria

Com base na constituição do sistema vocálico do português brasileiro, segundo Camara Jr. (1970), observam-se sete vogais em posição tônica, cujo número é reduzido diante de nasal, por eliminação das médias baixas. Em posição átona, o sistema apresenta cinco vogais pretônicas, quatro postônicas não-finais e três postônicas finais. Utilizando esse sistema como referência, constata-se que a assimetria entre os planos gráfico e fônico nas vogais está justamente na relação entre as letras 'e' e 'o' que representam as duas camadas de vogais médias, e eventualmente casos em que há alternância na pauta átona. Tem-se, portanto, até sete vogais fonológicas: /a/, /e/, / / /, /i/, /o/, / /, /u/ e cinco vogais gráficas: 'a', 'e', 'i,' 'o', 'u'.

Na perspectiva da fonologia autossegmental, seguindo Clements (1991), Wetzels (1992, p.22) propõe que traços de abertura determinam a altura das vogais:

$\begin{array}{lllll}\text { abertura } & \text { i/u } & \text { e/o } & \varepsilon / s & \text { a } \\ \text { aberto } 1 & - & - & - & + \\ \text { aberto } 2 & - & + & + & + \\ \text { aberto } 3 & - & - & + & +\end{array}$


Como se pode observar, é o valor do traço [aberto 3], neste modelo, que distingue as vogais médias altas das médias baixas. Em posição átona, portanto, as vogais médias baixas sofrem um processo de neutralização. Isso significa que, se a vogal não é acentuada, o traço [aberto 3] é desassociado, promovendo, assim o alçamento das médias baixas, como em /pi'poka/ $\rightarrow$ /pipokeiro/, em que / / passa para /o/, por exemplo.

Wetzels (1992) postula duas regras que são condicionadas prosodicamente. Isso significa que os fenômenos em questão dependem da estrutura prosódica da palavra. A primeira condição apontada por Wetzels (op.cit.) abarca as palavras com acento antepenúltimo: o abaixamento datílico prevê a proibição de vogais médias altas /e/ e /o/ na sílaba tônica de palavras proparoxítonas. Desse modo, as vogais médias nesta posição tendem a ser baixas, daí a denominação utilizada. O abaixamento datílico atua como uma regra em palavras derivadas (psicólogo; esquelético) e como uma restrição em palavras não-derivadas (médico; abóbora). Sendo uma característica própria de regras lexicais, o abaixamento datílico permite exceções, como nas proparoxítonas 'pêssego' e 'estômago', nas quais a tônica é uma vogal média alta.

A condição observada no abaixamento espondeu compreende as palavras portadoras de sílaba final pesada não-oxítonas, isto é, as paroxítonas acentuadas graficamente. Da mesma forma que no abaixamento datílico, o processo de neutralização das vogais médias pelo abaixamento ocorre na sílaba tônica, como em 'automóvel' e 'pólen'.

Tal configuração do sistema vocálico e seus processos fonológicos permitem afirmar que as vogais médias baixas / $/ \varepsilon / \mathrm{e} / \mathrm{\jmath} /$ são inerentes à posição tônica. Logo, as hipóteses das crianças a respeito da incidência do acento gráfico nas vogais médias baixas podem ser consideradas coerentes com o sistema fonológico da língua, já que majoritariamente não se observam contextos em que a vogal média baixa não coincida com a sílaba tônica da palavra.

A observação dos contextos de incidência das vogais em posição tônica na língua pode subsidiar a interpretação das hipóteses infantis relacionadas ao acento, principalmente a que atribui ao diacrítico a função indicadora de timbre, ao passo que as hipóteses das crianças tendem a confirmar o funcionamento da língua. Contudo, as justificativas analisadas nesta categoria adquirem mais validade na medida em que são descritas as demais hipóteses.

\subsection{Justificativas baseadas no alongamento/duração da vogal}

O alongamento da vogal tônica como critério apontado para justificar a pertinência do acento gráfico é importante na medida em que se constitui como um indício capaz de corroborar a hipótese teórica da correlação entre acento e peso silábico, tendo em vista a duração da vogal acentuada. Esta hipótese foi apontada por algumas crianças quando justificavam a necessidade do diacrítico nas palavras 'lâmpada, 'sofá,' 'búfalo,' 'príncipe' e 'vovồ. Para uma aproximação 
dos dados em análise, é pertinente observar alguns excertos de entrevistas que ilustram a referida hipótese:

Sofá. Se o sofá não tivesse acento, ficaria sofá...sofá...sofá. E agora que tem acento fica sofáaaaaa, fica um jeito bem melhor, e também tem um pouquinho...poderia ser um pouco sim, um pouquinho não precisaria ter o acento, um pouquinho não precisaria ter o acento pra mudar a palavra. Sofá...por um lado precisaria ter, só que...sofá... por um lado não precisaria ter... então cada um com um jeito, tipo tem gente que pensa que precisaria ter o acento e tem gente que pensa que não precisa ter o acento no sofá

E o que tu pensa?

Eu penso que teria que ter

Por quê?

Porque senão, não ficaria sofá, so-fá (silabou)

Ficaria como?

Sôfa...sofá...

Sôfa?

É, e com o acento fica so-fáaaaaa

Lê pra mim, sem o acento:

Sôfa...sôfa

Sôfa? Hum...o que mudou? O que mudou de sofá para sôfa?

Porque o 'A' ficou meio encolhido, como se ele tivesse com vergonha de falar o que ele representa e já com acento ele fala áááááá

No trecho apresentado, cujas respostas são de uma menina do terceiro ano, nota-se, em primeiro lugar, a pouca relevância atribuída ao acento gráfico, já que, na sua opinião, ele poderia ser opcional na palavra 'sofá, provavelmente influenciada por uma hipótese primária de que o acento serve para marcar o timbre. Além disso, verifica-se a sua percepção em relação à tonicidade, pois ela consegue, inclusive, alterar a posição do acento de 'sofá' para 'sôfa', demonstrando habilidade em identificar e produzir o contraste prosódico entre ambas as formas. A terceira constatação possível com base nesse exemplo é sua capacidade de atribuir a tonicidade da sílaba ao alongamento da vogal, uma vez que, ao supor que o acento deixa a palavra "de um jeito bem melhor", caracterizando a vogal átona como "encolhida" e a tônica representada por uma vogal longa, a criança revela uma hipótese coerente com as propostas teóricas que postulam a relação entre o peso silábico e duração. O trecho a seguir pertence à mesma entrevista; entretanto, as respostas foram desencadeadas a partir da reflexão sobre a grafia da palavra distratora 'macaco ${ }^{11}$ :

É porque assim: o 'A', tu colocando qualquer acento "de risquinho" nele não vai mudar nada, porque parece que já tem isso no 'A', então não tem necessidade de tu colocar no 'A'

E por que tu botou acento no sofá?

Pra ficar mais 'A' do que ele já é (risos)

As considerações feitas pela menina ratificam a hipótese acerca da função do acento como um marcador de timbre e, ao mesmo tempo, caracterizam a vogal tônica de 'sofá' como bimoraica, fato que estaria produzindo o efeito de peso silábico. 
O peso silábico é determinado pela estrutura interna da sílaba, a qual é constituída por ataque e rima. Quando uma rima é preenchida por apenas uma vogal, a sílaba é considerada leve, como em 'po' ou 'tra'; quando a rima é formada por uma vogal e uma consoante ou por duas vogais, a sílaba é pesada, como em 'par' ou 'lei'. Segundo Collischonn (2005), uma vogal longa também pode conferir peso à sílaba, cuja representação se dá a partir da sequência de dois elementos ' $\mathrm{V}$ '12 idênticos.

Na perspectiva de Hyman (1985), o peso silábico está relacionado à contagem das moras $(\mu)$, as quais são definidas como unidades de tempo que formam as sílabas. Com base nesta ideia, as sílabas pesadas têm duas moras e formam um constituinte. Uma sílaba CVC, por exemplo, tem duas moras; já uma sílaba CV, uma mora apenas. Ditongos e vogais longas possuem duas moras, sendo, portanto, elementos capazes de atribuir peso à sílaba.

Em linhas gerais, no português, a duração da vogal não é distintiva. Conforme descrito por Camara Jr. (1970), o sistema vocálico da língua portuguesa originou-se do latim clássico, cujo sistema fonológico de dez vogais alternava a duração correspondente aos cinco grafemas 'a', 'e', 'i', 'o' e 'u' entre vogais longas e breves. A transição diacrônica do latim para o português eliminou a duração como um traço distintivo na língua.

Hayes (1995), ao desenvolver a teoria métrica do acento, postulou a assimetria entre pés métricos com base em um universal perceptivo apontado pelos psicólogos Bolton (1894) e Woodrow (1909), os quais propuseram que os grupos de elementos rítmicos percebidos dependem do modo como eles são diferenciados, ou seja, por intensidade ou por duração. Assim, sequências de elementos que alternam a duração tendem a ser percebidas como iâmbicas, enquanto as que se diferem pela intensidade, como trocaicas. Tal proposição vai ao encontro da hipótese aqui descrita, posto que a percepção da oxítona em 'sofá, cujo formato prosódico é de um pé troqueu mórico, está relacionada à duração da vogal.

Bisol (1992, 1994), em sua proposta de atribuição do acento em português, defende a regra da Sensibilidade Quantitativa (SQ), a qual projeta a proeminência acentual à sílaba final de rima ramificada, cuja pauta acentual resultante é oxítona.

Figura 2 - Representação de sílaba leve e sílaba com rima ramificada

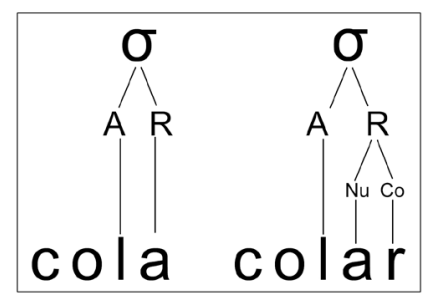

Fonte: Ney (2018)

Todavia, há divergências teóricas a respeito do status das oxítonas terminadas em vogal, já que, do ponto de vista de sua estrutura, não constituem rima ramificada. A proposição de Bisol (p. cit.) para estes casos consiste na atribuição 
do acento por SQ, devido à existência, na forma subjacente, de uma consoante abstrata na sílaba final, que se manifesta na derivação, recurso teórico caracterizado por cataláxis.

A cataláxis, para Hayes (1995), corresponde à presença de uma unidade segmentalmente vazia cuja posição métrica localiza-se à margem direita da palavra, constituindo, portanto, oposição à ideia de extrametricidade. O autor afirma que a posição catalética tem efeitos sobre o pé apenas nas palavras de um número ímpar de moras, permanecendo sem pés, portanto prosodicamente inertes, as palavras com um número par de moras.

No quadro 03 estão elencados outros exemplos de justificativas relacionadas ao acento que fazem alusão à duração da vogal em posição catalética:

Quadro 03 - Exemplos de justificativas que fazem alusão à duração da vogal em posição catalética

\begin{tabular}{|l|l|}
\hline palavra & \multicolumn{1}{c|}{ justificativa } \\
\hline sofá & {$[\ldots]$ deixa mais...so-fá, sofááá, entendeu? } \\
\hline vovô & $\begin{array}{l}\text { Vovô teria...sem o acento ia ficar vó... ia ficar...a-é-i-ó, então ia ficar vovô, só que pra ficar } \\
\text { vôoooo, tipo quando a gente chama vôoooo, se a gente não chamasse ia ficar vó-vô-vô... } \\
\text { também é uma palavra que não teria sentido como eu tinha dito nas outras, com ou sem } \\
\text { acento não muda, porque a-e-i-o-u }\end{array}$ \\
\hline
\end{tabular}

Fonte: Elaboração própria

As justificativas expressas no quadro 03 mostram que as crianças têm dificuldade para explicar a pertinência do acento gráfico sem buscar o apoio na alternância de timbre. Nas explicações referentes a 'vovô', o alongamento da vogal como critério para a grafia do acento reforça a hipótese acerca da duração como um contributo ao peso silábico.

No quadro 04 constam excertos que fazem referência à duração da vogal nas proparoxítonas, em 'lâmpada,' 'príncipe' e 'búfalo':

Quadro 04 - Exemplos de justificativas de atribuição do acento gráfico baseadas na duração da vogal

\begin{tabular}{|c|c|}
\hline palavra & justificativa \\
\hline \multirow[t]{2}{*}{ lâmpada } & $\begin{array}{l}\text { Tá, mas me explica com as tuas palavras, o que deixa, o que o acento faz nessa } \\
\text { palavra? } \\
\text { Deixa mais alto } \\
\text { Mais alto? } \\
\text { (Concordou) } \\
\text { E se a gente tirar, fica como? } \\
\text { lâmpada (falou rápido) } \\
\text { lâmpada? } \\
\text { É, fica mais rápido }\end{array}$ \\
\hline & $\begin{array}{l}\text { Eu acho que precisa...lâmpada (alongou o a) ... lâ-pada...fica lâmpada...lâm-pada... } \\
\text { (pequena pausa após -lam) }\end{array}$ \\
\hline \multirow{2}{*}{ príncipe } & príncipe, príncipe (sussurra). Muda...tipo que nem a lâmpada \\
\hline & Príncipe, e do jeito com o acento, príncipe (alongou -prin) \\
\hline
\end{tabular}




\begin{tabular}{|l|l|}
\hline \multirow{3}{*}{ búfalo } & $\begin{array}{l}\text { Pra hum...búfalo, pra dar aquele tom, porque ouvi que búfalo, búfalo... } \\
\text { Hum, pra dar que tom? Me explica mais... } \\
\text { Pra dar búúúfalo...búfalo }\end{array}$ \\
\hline
\end{tabular}

Fonte: Elaboração própria

Para os exemplos apresentados no quadro 04 cabe ressaltar que as vogais tônicas de 'lâmpada' e 'príncipe' são nasalizadas, logo, o peso é atribuído à presença de uma estrutura do tipo $\mathrm{VN}$, portanto, bimoraicas. A referência à duração da vogal acentuada em 'búfalo' pode ser interpretada pelo seu timbre fechado. De acordo com Meillet (1908), "é fácil de se compreender a passagem das vogais longas para o timbre fechado, sobretudo porque uma pronúncia mais fechada causa um aumento da impressão de longura”.

\subsection{Justificativas baseadas na tonicidade/proeminência/volume}

Tomando-se por base o funcionamento do acento prosódico do português brasileiro, o acento gráfico constitui-se como um recurso visual capaz de indicar a tonicidade das palavras que fogem à regra da língua. Logo, toda justificativa de grafia do acento que referencie a tonicidade, proeminência, força ou volume pode ser interpretada como uma hipótese coerente com a organização prosódica da língua e com o sistema ortográfico, por estar em consonância com a função primordial do acento na ortografia.

As palavras que tiveram seus acentos justificados pela tonicidade com maior recorrência foram 'búfalo, 'sofá, 'tênis' e 'lápis', embora todas as palavras tenham recebido pelo menos uma menção à tonicidade da sílaba como critério para a necessidade de grafia do acento. O acento gráfico de 'automóvel' é o que menos foi explicado por esta justificativa, com apenas uma citação nas entrevistas.

Considerando a tonicidade como referência de análise, os dados desta categoria foram agrupados pela posição do acento. O quadro 05 apresenta os excertos das entrevistas relativos ao acento gráfico das oxítonas, 'sofá, 'boné' e 'vovồ:

Quadro 05 - Exemplos de justificativas de necessidade de grafia do acento relacionadas à tonicidade nas palavras oxítonas

\begin{tabular}{|c|c|}
\hline palavra & exemplos de justificativa \\
\hline \multirow[b]{3}{*}{ sofá } & porque é so-fá...mais forte \\
\hline & Ela dá mais som no 'a', no final \\
\hline & $\begin{array}{l}\text { Pra que serve? } \\
\text { Pra aumentar o tom, assim, tipo numa sílaba tônica...deixar mais forte, sofá...mais... } \\
\text { Pra deixar mais forte? O que é sílaba tônica? } \\
\text { Ah, sílaba tônica é... é uma sílaba que tem acento assim, que nem eu te disse, pra deixar } \\
\text { a sílaba mais forte }\end{array}$ \\
\hline boné & $\begin{array}{l}\text { Por causa que como eu...eu pensei...eu pensei vovó...vovô...então eu pensei que esse } \\
\text { acento é maior e boné tem um acento maior, então eu pensei que era assim e coloquei } \\
\text { esse }\end{array}$ \\
\hline vovô & Quando bota ele fica um som mais grosso, assim, mais forte \\
\hline
\end{tabular}

Fonte: Elaboração própria 
Os trechos selecionados revelam, de um lado, a hipótese acerca da função do acento gráfico atrelada à sílaba mais proeminente, de outro, a dificuldade das crianças em conceituar a tonicidade observada na sílaba portadora do acento. Apenas uma, das 14 crianças entrevistadas, utilizou a denominação "sílaba tônica" para se referir à sílaba mais proeminente da palavra.

Reitera-se que o pé troqueu mórico - desenho prosódico das oxítonas - é típico da língua portuguesa nas palavras terminadas em sílaba pesada. Quando terminadas em sílabas leves, as palavras oxítonas são explicadas pelo recurso da cataláxis.

Nos dados de escrita, observa-se que o maior índice de acertos no ditado de imagens é na grafia das oxítonas (64\%), seguido das paroxítonas (27\%) e das proparoxítonas (23\%), conforme expresso na tabela 07 :

Tabela 07 - Distribuição dos dados de escrita produzidos no ditado de imagens, por pauta acentual

\begin{tabular}{|c|c|c|c|c|c|c|c|}
\hline \multirow{2}{*}{ pauta } & \multicolumn{2}{|c|}{ acertos } & \multicolumn{2}{|c|}{ omissões } & \multicolumn{2}{|c|}{ demais casos } & \multirow{2}{*}{ total } \\
\hline & $3^{\circ}$ & $5^{\circ}$ & $3^{\circ}$ & $5^{\circ}$ & $3^{\circ}$ & $5^{\circ}$ & \\
\hline \multirow{2}{*}{ oxítona } & 11 & 16 & 09 & 03 & 01 & 02 & \multirow{2}{*}{42} \\
\hline & \multicolumn{2}{|c|}{27 (64\%) } & \multicolumn{2}{|c|}{$12(29 \%)$} & \multicolumn{2}{|c|}{$03(07 \%)$} & \\
\hline \multirow{2}{*}{ paroxítona } & 03 & 16 & 28 & 14 & 04 & 05 & \multirow{2}{*}{70} \\
\hline & \multicolumn{2}{|c|}{$19(27 \%)$} & \multicolumn{2}{|c|}{$42(60 \%)$} & \multicolumn{2}{|c|}{09 (13\%) } & \\
\hline \multirow{2}{*}{ proparoxítona } & 06 & 10 & 28 & 24 & 01 & 01 & \multirow{2}{*}{70} \\
\hline & \multicolumn{2}{|c|}{$16(23 \%)$} & \multicolumn{2}{|c|}{$52(74 \%)$} & \multicolumn{2}{|c|}{$02(03 \%)$} & \\
\hline subtotal & 20 & 42 & 65 & 41 & 06 & 08 & \multirow{2}{*}{182} \\
\hline total & \multicolumn{2}{|l|}{62} & \multicolumn{2}{|c|}{106} & \multicolumn{2}{|l|}{14} & \\
\hline
\end{tabular}

Fonte: Ney (2018)

A tendência ao emprego adequado do acento em vocábulos oxítonos é atestada em Ney $(2012,2018)$. No entanto, do ponto de vista das hipóteses observadas, o formato do pé troqueu mórico parece não ser um critério relevante para o uso do acento nas oxítonas cujas vogais tônicas são médias, já que as justificativas de grafia do acento em 'vovồ e 'boné', apresentadas pela maioria das crianças, parecem evidenciar o timbre vocálico como critério primordial para a acentuação. A ideia relacionada à tonicidade, à percepção de uma sílaba mais forte, com “mais som", é predominante, portanto, na palavra 'sofá. As justificativas atribuídas à pertinência do acento em 'sofá' dividem-se, de forma equitativa, entre os critérios de tonicidade, como apresentado no quadro 13, memória gráfica e incertezas sobre a sua necessidade de grafia.

A seguir serão apresentados os exemplos que ilustram as hipóteses das crianças sobre o acento gráfico como um marcador de tonicidade nas palavras paroxítonas. $\mathrm{O}$ exemplo que segue revela a consciência metalinguística da criança por meio das justificativas apresentadas ao refletir sobre a grafia do acento na palavra 'vírus'. $\mathrm{O}$ trecho pertence a uma entrevista realizada com uma criança do quinto ano: 


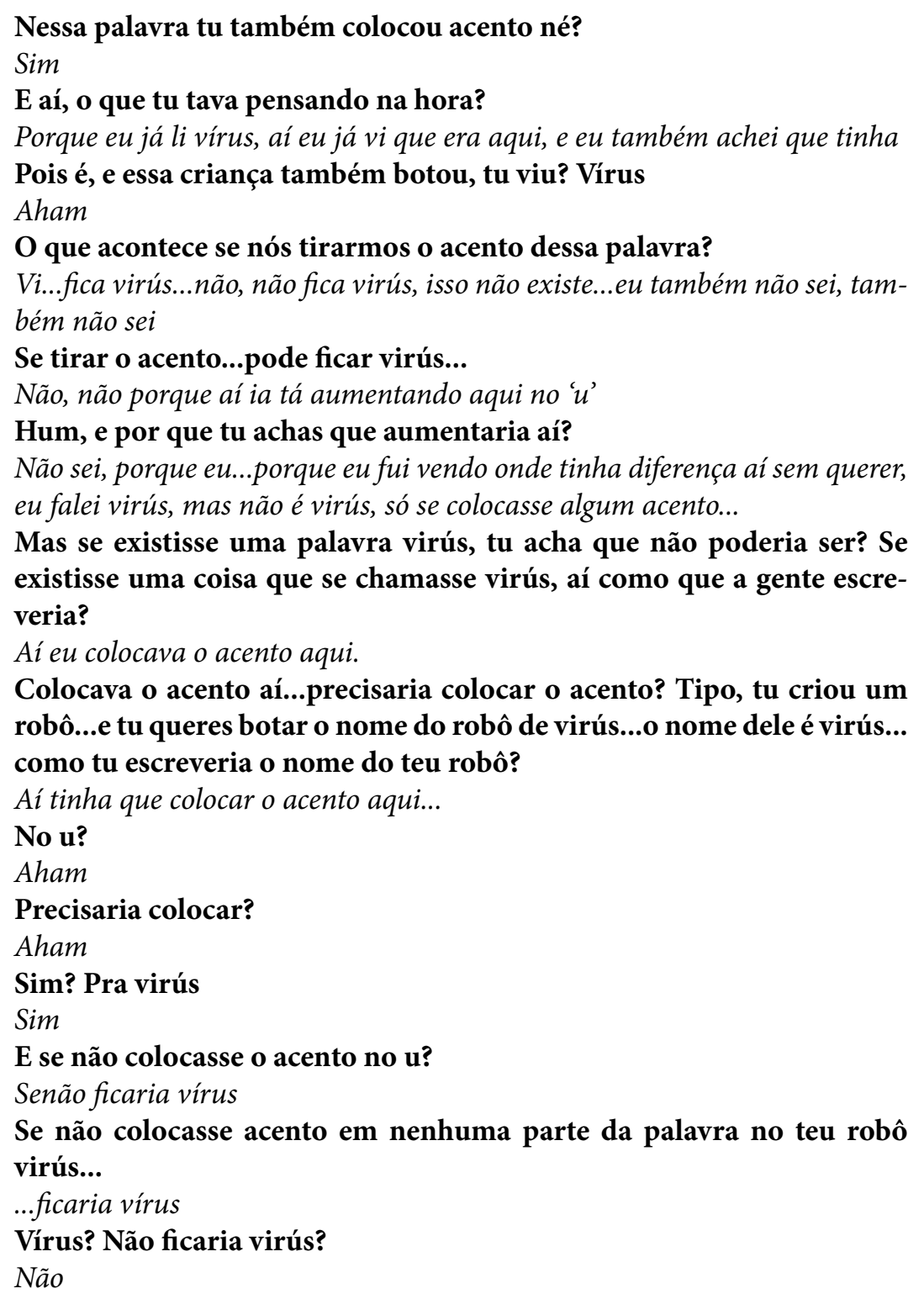

Nota-se que o acento é atribuído à tonicidade; entretanto, verificam-se as incertezas sobre a relação entre a fala e a escrita, pois inicialmente ele supõe que a supressão do diacrítico alteraria a tonicidade da sílaba, passando de 'vírus' para 'virús', manifestando, assim, seu conhecimento prosódico internalizado, visto que o acento é atraído pelo peso silábico. Logo após muda de opinião e diz que "sem querer" falou 'virús', e que a tonicidade só seria alterada mediante a grafia de um acento na sílaba final.

No quadro 06 foram elencados outros exemplos de justificativas em que o acento gráfico é atribuído à proeminência da sílaba em paroxítonas: 
Quadro 06 - Exemplos de justificativas de necessidade de grafia do acento relacionadas à tonicidade nas palavras paroxítonas

\begin{tabular}{|c|c|}
\hline palavra & exemplos de justificativas \\
\hline \multirow{4}{*}{ lápis } & Porque ela fica la-pis (silabado). E esse daqui ia ficar lápis, lápis. Ele fica mais agudo. \\
\hline & Forte...láááápis \\
\hline & (...) porque...porque eu coloquei também pra aumentar...pra aumentar a palavra... a sílaba \\
\hline & É, o 'la’ é o som mais forte, eu já sabia que tinha (...) \\
\hline \multirow[b]{3}{*}{ tênis } & Tá deixando a palavra um pouco mais forte e mais aguda \\
\hline & Ora, porque ele, tipo a palavra tênis, 'te', deixa um pouco mais forte a palavra \\
\hline & $\begin{array}{l}\text { Esse é...tipo ficou mais pra baixo, ele ficou tipo tê-nis...tênis } \\
\text { Entendi... } \\
\text { Mais forte } \\
\text { E tu acha que precisa...entendi...tu acha que fica mais forte? } \\
\text { Sim, mais... (sinais com as mãos pra cima) }\end{array}$ \\
\hline vírus & Pra... dar um som no 'i’ \\
\hline \multirow{3}{*}{ túnel } & $\begin{array}{l}\text { Deixa um pouquinho mais forte, mas bem pouco, porque o u já é mais forte na palavra } \\
\text { túnel }\end{array}$ \\
\hline & Pra... 'tu', pra ficar mais agudo \\
\hline & $\begin{array}{l}\text { Eu não sei exatamente pra que serve o acento no u... (...) } \\
\text { Porque a sílaba tônica é tuuuunel, e eu vi que se ficar sem acento não, não fica muito } \\
\text { familiar, aí então eu coloco o acento...porque eu acho que é assim }\end{array}$ \\
\hline
\end{tabular}

Fonte: Elaboração própria

Nos trechos apresentados, embora seja possível identificar que algumas crianças expressam a tonicidade por meio do alongamento da vogal tônica, suas explicações verbalizam os critérios de tonicidade, força ou volume, diferentemente da categoria recém apresentada. Estes dados sugerem, portanto, uma estreita relação entre tonicidade e duração da vogal, as quais são percebidas pelas crianças e manifestas através de suas hipóteses sobre a organização prosódica da língua.

Dentre as hipóteses sobre o acento gráfico em palavras proparoxítonas, foram observadas justificativas alusivas à tonicidade em todas as palavras-alvo, sendo que o maior número de referências a este critério é relativo à palavra 'búfalo', e o menor número corresponde à palavra 'lâmpada'. Dentre as três pautas acentuais observadas no português, pode-se dizer que o acento gráfico é inerente ao padrão proparoxítono, uma vez que o que é considerado prosodicamente marcado na fonologia é representado graficamente no sistema ortográfico. Trata-se, portanto, de uma regra invariável: todas as proparoxítonas são graficamente acentuadas.

A análise dos dados de aquisição da escrita mostra que o maior índice de erros se concentra nas palavras proparoxítonas. Em Ney (2012) foi verificado um percentual de $72 \%$ de erros de grafia em proparoxítonas. Nos dados de escrita espontânea descritos em Ney (2018), o índice de acertos em proparoxítonas é de apenas $20 \%$, e nas grafias produzidas no ditado de imagens somente 16 das 70 proparoxítonas foram acentuadas corretamente. Metade dos erros em proparoxítonas correspondem às palavras 'príncipe' e 'búfalo' (somam 27 omissões). Os 
dados obtidos nas entrevistas indicam que, de modo geral, as crianças acham que o acento é dispensável na maioria das palavras cuja vogal tônica não sofre variação de timbre. Entre aquelas que manifestaram a concordância a favor da grafia do acento como um indicador de tonicidade, pode-se listar algumas das suas justificativas:

Quadro 07 - Exemplos de justificativas de necessidade de grafia do acento relacionadas à tonicidade nas palavras proparoxítonas

\begin{tabular}{|c|c|}
\hline palavra & exemplos de justificativas \\
\hline \multirow[b]{2}{*}{ lâmpada } & Deixa mais alto \\
\hline & $\begin{array}{l}\text { E também porque lendo fica lââmpada, tipo aqui é a sílaba tônica, então por isso que } \\
\text { eu escolhi (...) que é a sílaba mais forte da palavra, porque lendo assim ó, fica lâââm- } \\
\text { pada, lendo assim, aí fica...aî vê qual a palavra que sobe }\end{array}$ \\
\hline \multirow{3}{*}{ médico } & $\begin{array}{l}\text { É, o que o acento faz nessa palavra médico? } \\
\text { Dá mais som nas vogais }\end{array}$ \\
\hline & Por causa que o som fica mais agudo...mais forte, quer dizer \\
\hline & $\begin{array}{l}\text { Para quê tu achas que serve esse acento aqui na palavra médico? } \\
\text { Ah, pra dar volume assim }\end{array}$ \\
\hline \multirow[t]{2}{*}{ príncipe } & $\begin{array}{l}\text { Deixa mais...um pouco mais de som na palavra inteira } \\
\text { Com mais som? Qual é o som que fica, que aumenta? } \\
\text { Príncipe, então deixa mais, o 'prin' mais forte }\end{array}$ \\
\hline & É como eu te disse...pra... deixar... pra deixar mais forte a sílaba \\
\hline \multirow[t]{2}{*}{ abóbora } & $\begin{array}{l}\text { Hum. Então pra que serve esse acento na palavra? Pra que tu acha que ela botou } \\
\text { acento na palavra? } \\
\text { Pra não ficar tipo, tudo a mesma coisa, aboborá...abó-bo-ra } \\
\text { Hum, então pra que serve o acento nas palavras? } \\
\text { Pra dar...um som maior na palavra }\end{array}$ \\
\hline & Porque deixa o 'o' mais forte \\
\hline \multirow[t]{2}{*}{ búfalo } & $\begin{array}{l}\text {...tipo...tipo, acho que não...o acento tá aqui...tipo não pra mudar a palavra, mas sim } \\
\text { pra fazer dela a sílaba tônica, porque senão...se tivesse aqui essa que seria a sílaba } \\
\text { tônica }\end{array}$ \\
\hline & Porque deixa o 'u' mais forte, búfalo \\
\hline
\end{tabular}

Fonte: Elaboração própria

Os exemplos citados no quadro 07 ilustram as referências das crianças à tonicidade por meio de diferentes formas de conceituá-la: deixar mais alto; "dar mais som"; "dar mais volume"; "dar um pouco mais de som"; "dar um som maior"; "deixar mais agudo"; "deixar mais forte"; "mudar o tom"; diferenciar ("pra não ficar tudo a mesma coisa"), "pra marcar a sílaba tônica", "a mais forte da palavra", entre outras. Pode-se dizer que as diversas formas observadas constituem modos heterogêneos de expressar o conhecimento linguístico das crianças, tendo em vista que, mesmo que os aspectos ortográficos ainda não estejam consolidados, as diferentes designações observadas para justificar o acento gráfico demonstram sua percepção à existência de uma sílaba mais proeminente que a(s) outras(s). 


\section{Considerações finais}

Neste artigo, cujo objetivo foi refletir sobre o acento gráfico em sua relação com a prosódia bem como sobre os usos que dele fazem alunos do terceiro e do quinto ano do Ensino Fundamental, foi feito um exercício de análise que possibilitou a reconstrução das hipóteses formuladas pelas crianças. Os resultados obtidos, a partir dos dados de produção escrita e, especialmente, daqueles obtidos por meio das entrevistas clínicas, mostram a influência de uma fonte principal para as respostas dadas, o conhecimento linguístico. Já o conhecimento referente ao sistema de escrita, especificamente o ortográfico, revela-se quase inoperante, à exceção de casos em que o uso do acento decorre de memória visual.

Do ponto de vista do conhecimento linguístico, subjacente às justificativas dadas pelas crianças para o uso ou não do acento gráfico, pôde-se observar que critérios acústicos, tais como a frequência dos formantes, a ressonância nasal, a duração e a intensidade, são evocados pelas crianças durante as entrevistas clínicas realizadas, método que se mostrou capaz de iluminar as grafias produzidas.

O processo de escolarização, se desenvolvido com base em abordagens didáticas adequadas que priorizem a relação entre a acentuação gráfica e o funcionamento da língua, poderia inverter a lógica extraída das respostas das crianças, uma vez que a compreensão a respeito da função do uso do diacrítico no sistema de escrita exigiria maior ênfase no critério de intensidade/ tonicidade, o qual seria fundamental para que o efeito de marcação das formas acentuadas pudesse ser percebido. Quanto ao critério que aparece de forma mais robusta nos dados, qual seja, o da frequência dos formantes, responsável pela diferenciação entre vogais médias baixas e médias altas, é importante considerar que ele não está relacionado ao acento gráfico, mas sim à assimetria entre os fonemas vocálicos e seus respectivos grafemas. No entanto, ainda constam em livros didáticos (Ney e Miranda, 2010) e nas práticas dos professores justificativas para o uso do acento com base na ideia errônea de que sua função é registrar a mudança de timbre das vogais médias. Entende-se que estudos como este, que se propõe a desenvolver uma análise dos processos de pensamento, podem oferecer subsídios para a interpretação não só do conhecimento de língua que emerge dos erros, mas também para que se reflita sobre o próprio funcionamento fonológico da língua alvo.

\section{Notas}

1. A Epistemologia Genética de Jean Piaget (1972) configura-se como uma teoria geral dos processos de aquisição de conhecimento, na qual o sujeito cognoscente está em constante reestruturação cognitiva, passando de estágios de desenvolvimento da inteligência menos elaborados a outros qualitativamente superiores.

2. Dentre os cinco níveis descritos pelas autoras, os dois primeiros receberam as denominações de pré-silábico I e pré-silábico II; o terceiro de silábico, considerado um marco conceitual porque anuncia o surgimento das relações entre os níveis fônico e gráfico; o quarto de silábico-alfabético e o quinto e último de alfabético. Estes níveis são identificados a partir da criança que aprende, de acordo com as hipóteses que ela vai construindo sobre o objeto de conhecimento em questão, a escrita. 
3. O instrumento completo e seu protocolo de aplicação podem ser consultados em Ney (2018).

4. O estudo foi realizado com o aceite dos participantes e com o Termo de Consentimento Livre e Esclarecido assinado por seus respectivos responsáveis.

5. Reitera-se que as palavras 'abacaxi' e 'tatu' ( 28 ocorrências) foram retiradas desta amostra de análise porque não são acentuadas graficamente.

6. Ressalta-se que há somente dois casos de erros para o item 'vovô', ambos no terceiro ano: num deles, o acento foi trocado pelo agudo, o que poderia ser considerado um acerto em se tratando da marcação de tonicidade, critério utilizado anteriormente em Ney (2012), em que se classificou a troca como acerto com o tipo errado. O segundo caso é de omissão, produzido por uma criança que não grafou acento em nenhuma das palavras escritas no ditado.

7. Resultados do teste de sensibilidade ao acento prosódico desenvolvido por Ney (2018) indicam que as vogais altas representam dificuldades para as crianças na tarefa de percepção dos contrastes prosódicos.

8. Uma criança, do quinto ano, grafou 'lapís', porém seu traçado do 'pingo do i' se assemelha a um acento agudo. Durante a entrevista, não deixou claro se havia acentuado ou não, ora dizia que sim, ora negava. Optou-se, após análise de todas as palavras escritas no ditado e de suas respostas na entrevista, por considerar os tracinhos grafados como pingos do i, e não acentos, classificando os casos em questão como omissões.

9. A metátese caracteriza-se pela transposição de fonemas no interior de uma palavra. As metáteses podem ser intrassilábicas (/prato/ > /parto/) ou intersilábicas (/ prato/ > /patro/).

10. Nos quadros ilustrativos foram selecionados os exemplos mais diversificados e representativos.

11. Ainda que as palavras distratoras não tenham sido objeto de análise, algumas respostas referentes à estas palavras foram consideradas por apresentaram reflexões importantes para o estudo.

12. 'V' representa a classe 'vogal' e 'C', a classe 'consoante'.

\section{Referências}

AMARAL, M. P. do. As proparoxítonas: teoria e variação. Tese (Doutorado em Letras (Linguística Aplicada)) Faculdade de Letras, PUCRS, Porto Alegre/RS, 2000.

BOLTON, Thaddeus L. Rhythm. American Journal of Psychology 6, 145-238, 1894.

BISOL, L. O acento e o pé binário. Letras de Hoje (98). Porto Alegre/RS: PUCRS, v.29, n.4, p.25-36, 1994.

BISOL, L. O acento e o pé métrico binário. Cadernos de Estudos Linguísticos, n. 22, p.69-80. Campinas/SP: UNICAMP, 1992.

CAGLIARI, L. C. Elementos de Fonética do Português Brasileiro. São Paulo: Paulistana. 2007.

CAMARA JR., J. M. Estrutura da língua portuguesa. Petrópolis: Vozes, 1970.

CARRAHER, T.N. O método clínico: usando os exames de Piaget. São Paulo: Cortez, 1989.

CLEMENTS, G. N. Place of articulation in consonants in vowels: a unified theory. Working Papers of the Cornell Phonetics Laboratory, n.5, 1991. 
COLLISCHONN, G. A sílaba em português. In: BISOL, L. (Org.) Introdução a estudos de fonologia do português brasileiro.4.ed. revista e ampliada. Porto Alegre/RS: EDIPUCRS, 2005, p. 101- 130

FERREIRO, E.; TEBEROSKY, A. Psicogênese da língua escrita. Porto Alegre/RS: Artes Médicas, 1985.

HAYES, B. Metrical Stress Theory: Principles and Case Studies. Chicago: University of Press, 1995.

HYMAN, L. M. A Theory of Phonological Weight. Dordrecth: Foris, 1985.

MEILLET, A. Introduction a Létude Comparative des Langues Indo Européennes. Paris: Librairie Hachette, 1903 [1908].

MIRANDA, A.R.M. Aquisição da linguagem: escrita e fonologia. In. LAZZAROTOVOLCÃO C. e FREITAS M.J. (orgs.). Estudos em Fonética e Fonologia - coletânea em homenagem a Carmen Matzenauer. Curitiba: CRV, 2018, p. 335-364.

MIRANDA, A.R.M. A fonologia em dados de escrita inicial de crianças brasileiras. Linguística (Madrid), v. 30, p. 45-80, 2014.

MIRANDA, A.R.M. Reflexões sobre a fonologia e a aquisição da linguagem oral e escrita, Veredas (UFJF), online, 16, p.118-135, 2012.

MIRANDA, A.R.M. Os dados de aquisição oral e escrita e o estatuto das codas mediais do português. In: FERREIRA-GONÇALVES, G.; KESKE-SOARES, M.; BRUM-DE-PAULA, M (Org.). Estudos em Aquisição Fonológica. Santa Maria: Pallotti, 2009, p. 111-130.

NEY, L. A. G; MIRANDA, A. R.M. A utilização do acento gráfico nos dados de escrita inicial e as propostas metodológicas nos livros didáticos de língua portuguesa: um estudo à luz da fonologia. Anais do XV Endipe, Belo Horizonte, UFMG, 2010, p. 2-14.

NEY, L. A. G. Acento gráfico e prosódico: um estudo sobre as hipóteses de crianças dos anos iniciais. Tese (Doutorado em Educação) - Faculdade de Educação, UFPel, Pelotas/RS, 2018.

NEY, L. A. G. Acentuação gráfica na escrita de crianças de séries iniciais. Dissertação (Mestrado em Educação) - Faculdade de Educação, UFPel, Pelotas/RS, 2012.

PIAGET, J. A epistemologia genética. Petrópolis/RJ: Editora Vozes, 1972.

WETZELS, L. Mid vowel neutralization in Brazilian Portuguese. Cadernos de Estudos Linguísticos. Campinas, n. 23, p. 19-56, 1992

WOODROW, Herbert. A quantitative study of rhythm. Archives of Psychology (New York) 14, 1-66, 1909. 